\title{
Death Anxiety among Handicapped and Normal Women
}

\author{
Dr. D. A. Dadhania ${ }^{1}$
}

\section{ABSTRACT:}

The present study is main aim was to comparative study of death anxiety among handicapped and normal women. The study was conducted on a sample consisted of 90 people out which 45 were handicapped women and 45 normal women in Jamnagar city (Gujarat). Collected data from the women as Death Anxiety scale - by Prof. K. D. Broata. The obtained data were analyzed though ' $t$ ' test to know the mean difference between the two groups handicapped women and normal women. The results show that there is significant difference in the death anxiety level of the normal women and handicapped women.

Keywords: Death Anxiety, handicapped

Death anxiety is the morbid, abnormal or persistent fear of one's own mortality. One definition of death anxiety is a "feeling of dread, apprehension or solicitude (anxiety) when one thinks of the process of dying, or ceasing to 'be'". It is also referred to as than to phobia (fear of death), and is distinguished from necrophilia, which is a specific fear of dead or dying persons and/or things (i.e. others who are dead or dying, not one's own death or dying). Lower ego integrity, more physical problems, and more psychological problems are predictive of higher levels of death anxiety in elderly people. Death anxiety refers the fear of and anxiety related to the anticipation, and awareness, of dying, death, and nonexistence. It typically includes emotional, cognitive, and motivational components that vary according to a person's stage of development and sociocultural life experiences (Lehto \& Stein,2009).

Death anxiety is associated with fundamental brain structures that regulate fight-or-flight responses and record emotionally charged explicit and implicit memories (Panksepp, 2004). Cognitive dimensions of death anxiety can include an awareness of the salience of death and a variety of beliefs, attitudes, images, and thoughts concerning death, dying, and what happens after death (Lehto \& Stein, 2009). Death anxiety can be experienced consciously or unconsciously; it can motivate individuals to ameliorate their death anxiety through distraction (Greenberg, Pyszczynski, Solomon, Simon, \& Breus, 1994), attempts to enhance. Death is considered a universal reaction. It has.

\footnotetext{
${ }^{1}$ Associate Professor, Shri V. M. Mehata Arts College, Jamnagar, saurashtra university. 


\section{Death Anxiety among Handicapped and Normal Women}

Another major transformation that occurred in hematological theory and research involved the recognition that individuals can also have positive views and feelings about death. Death is not always viewed completely negatively. For instance, death can give life meaning and can accentuate a positive philosophy of life. People can view death positively, for instance, if it brings relief of pain and suffering, gives loved ones a chance to come together and express their care and concern for each other, or if death and dying helps to refocus attention on important personal values and needs. Finally, dealing with death can reveal strengths in terminally ill individuals, their family members and friends, and health care professionals. In sum, attitudes and feelings about death are multidimensional, and people can simultaneously have both positive and negative sentiments about a broad array of death-related phenomena.

There have been substantial changes in the way Western scientists have interpreted or understood the concept of death anxiety. Early writings, which were heavily influenced by psychodynamic theory, stressed that fear and anxiety about death were universal, and, in an attempt to deal with their neurotic concerns about death, most individuals repressed or denied their true, negative feelings. In other words, everyone feared or was anxious about death, no matter what they said or how they acted. As death research matured, however, investigators discovered not only that some people actually had little or no anxiety about death, but also that the term death anxiety was really a misnomer for a variety of related negative reactions to death. These reactions include elements of fear, anxiety, concern, threat, worry, and confusion, and they can be focused on different death-related issues. For instance, distinctions should be made regarding anxiety about one's own death or the deaths of others, reactions to a painful dying process, uncertainties about when and how one will die, and concerns about an afterlife.

\section{OBJECTIVE}

The purpose of present investigation was to investigate symptoms of death anxiety in handicapped and normal women.

\section{HYPOTHESIS}

1. To study the death anxiety of handicapped women.

2. To study the death anxiety of normal women.

3. To study the difference between death anxiety among handicapped women and normal women.

\section{VARIABLE:-}

\section{Independent Variable:}

Woman Types:

Handicapped women and normal women. 


\section{Dependent Variable:}

Score on death anxiety scale.

\section{SAMPLE:-}

The present study sample was selected simple random methods. The sample of present study consist 90 people living in the various society areas of Jamnagar city (Gujarat). It consist 45 handicapped women and 45 normal women.

\section{TOOLS:-}

(1) Personal Data sheet.

(2) Death Anxiety scale - by Prof. K.D. Broata

\section{STATISTICAL ANALYSIS:-}

' $\mathrm{t}$ ' test was applied to know the difference between the death anxiety level of handicapped women and normal women

\section{TABLE}

\begin{tabular}{|l|l|l|l|l|l|}
\hline Group & N & MEAN & SD & t & Sing. \\
\hline $\begin{array}{l}\text { Handicapped } \\
\text { Women }\end{array}$ & 45 & 87.44 & 13.84 & 2.68 & 0.01 \\
\hline Normal Women & 45 & 80.01 & 12.80 & & \\
\hline
\end{tabular}

The above table shows the levels of death anxiety of handicapped women and normal women. Where in handicapped women mean is 87.44 where as for normal women it is 80.01 and SD13.84 and 12.80 for both castes. ' $t$ ' level value is 2.68 and its level of sig is 0.01 " $t$ " score of handicapped women and normal women is 2.68 it is more than critical value $2.59(0.01)$. So it is significant. The hypothesis that "To study the difference between death anxiety among handicapped women and normal women." is rejected. 


\section{CONCLUSION:-}

There was significant difference between handicapped women and normal women regarding the level of death anxiety. It means level of death anxiety more in handicapped women.

\section{REFERENCE:-}

Durlak, J. A., and Riesenberg, L. A. "The Impact of Death Education." Death Studies 15 (1991): 39-58.

Neimeyer, R. A., ed. Death Anxiety Handbook: Research, Instrumentation, and Application. Washington, D.C.: Taylor and Francis, 1994.

Neimeyer, R. A., and Vanbrunt, D. "Death Anxiety." In Dying: Facing the Facts,3d ed. Edited by H. Wass and R. A. Neimeyer. Washington, D.C.: Taylor and Francis, 1995. Pages 49-88.

Ring, K. Life at Death: A Scientific Investigation of the Near-Death Experience.New York: Quill, 1982. 